\title{
Metacognitive skill assessment model through the blended learning management system in vocational education
}

\author{
Ridwan Daud Mahamde *, Fitrah Asma Darmawan, Jasruddin Daud Malago \\ Universitas Negeri Makassar. \\ J1. A. P. Pettarani, Rappocini, Makassar, Sulawesi Selatan 90222, Indonesia. \\ * Corresponding Author. Email: ridwandm@unm.ac.id
}

\section{ARTICLE INFO}

\section{Article History}

Received:

12 December 2020;

Revised:

14 January 2021;

Accepted:

8 February 2021;

Available online:

9 June 2021

\section{Keywords}

Blended learning management system; Metacognitive skill; Project-based learning; Vocational education

\begin{abstract}
This study aims to develop an assessment rubric and produce a metacognitive skill model through the Blended Learning Management System (BLEMS) in project-based learning in vocational education. This study uses the Research and Development (R\&D) model of Borg and Gall (1983). The research subjects consisted of two experts (validity), ten students (small group), and 35 students (expanded) from the Faculty of Engineering, Universitas Negeri Makassar, Indonesia. Data were collected using questionnaires and tests: developed assessment instruments and rubrics with three main aspects, planning, monitoring, and evaluation. Conducted assessment tests through self, peer, and teacher assessments. Then analyzed the results of the Assessments with descriptive statistics. The results showed that the Rubric and metacognitive assessment model through BLEMS for vocational education met the validity, practicality, and effectiveness. The integration of metacognitive skill elements: planning, monitoring, and evaluation with self-assessment, peer assessment, and teacher assessment can be an assessment method to measure students' metacognitive thinking skills in project-based learning in vocational education.
\end{abstract}

This is an open access article under the $\mathrm{CC}-\mathrm{BY}-\mathrm{SA}$ license.

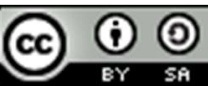

How to cite:

Mahamde, R. D., Darmawan, F. A., \& Malago, J. D. (2021). Metacognitive skill assessment model through the blended learning management system in vocational education. Jurnal Pendidikan Vokasi, 11(1), 1-13. https://doi.org/10.21831/jpv.v11i1.36912

\section{INTRODUCTION}

The world of work, which is dynamic and develops according to technological progress, demands that workers have work competence (hard skills) in their fields and have soft skills. In terms of a dynamic and complex world of work, intelligence and soft skills are needed relevant to the world of work today and the world of work in the future (Mane \& Corbella, 2017). These soft skills are course adaptability, problem-solving, analytical thinking, creativity, collaboration, and communication. The International Labor Organization (ILO) released several soft skills needed in the world of work, such as analytical skills, creativity, problem-solving, communication, collaboration, and entrepreneurship (International Labour Organisation (ILO), 2019). Some of these soft skills, such as 
analytical skills, creativity, and problem-solving abilities, are classified as critical thinking, regulated by the ability to think reflective or metacognitive thinking (Gotoh, 2016). Metacognitive abilities help individuals control, organize, and understand their cognitive system processes (Altiok et al., 2019; Yusuf et al., 2017). Therefore, the ability to think metacognition is very important for individuals to maintain a work ethic in a very dynamic work world with change and uncertainty.

Vocational education, an educational program that aims to prepare a competent workforce, is required to know the current world of work demands. UNESCO-UNEVOC has set one of the top priorities of vocational education globally, namely preparing a competent young workforce according to the global workforce's demands today. Vocational education, globally known as Technical and Vocational Education and Training (TVET), is required to equip students with hard skills and equip them with creative skills, analytical thinking, problem-solving, and leadership (Otero, 2019). Vocational education must integrate these soft skills into its curriculum. Also, vocational education institutions should carry out various learning innovations, both in learning planning, the learning process, and learning evaluation. Digitalization is one of the best choices because it demands the current digital era, leading to learning 4.0.

Learning 4.0 has now been promoted at various levels of education, including at the higher education level. The use of online learning is one of the learning media used to help the learning process digitally. The implications of online learning or e-learning in learning present new forms of learning and allow learners to collaborate and interact socially online (Mhouti \& Nasseh, 2017). Also, online learning can increase students' motivation levels (Kew \& Petsangsri, 2018) and help students access information and learning resources from anywhere and anytime (Al-araibi \& Naz, 2018). The use of e-learning in vocational education has also been widely using and research. The use of digital-based teaching materials integrated into e-learning can improve mathematics learning outcomes in vocational education (Zwart et al., 2017). Teachers and students use mobile devices for vocational learning purposes (Mahande et al., 2017). Learning evaluation is, of course, also possible to do online with the help of e-learning. With the advancement of internet technology and the increasing interest in online learning, issues around e-learning and its assessment methods are also getting more attention among educators (Hsu et al., 2009).

Based on researchers' limited interviews, online learning evaluations in education tend to be measured using multiple choice-based questions. The same is the case at Universitas Negeri Makassar, Indonesia. Multiple choice questions often operate in summative and formative tests in education (online and offline) (Costello et al., 2018). To measure students' higher-level cognitive thinking level is difficult if only using multiple-choice questions. Because in practice, the use of multiple-choice-multiple-choice touches low-order cognitive thinking (Xiong \& Suen, 2018). Therefore, it takes an evaluation form and a question form that allows students to explore their reflective and metacognitive thinking, subjective and objective. Through this metacognitive thinking, products expect to reflect on their learning and make adjustments to achieve a more in-depth understanding (Earl et al., 2006). A formative assessment is also needed that focuses on teaching studAlsoognitive processes to evaluate their learning and make adjustments to the learning process (Johnson, 2004).

Several studies have examined methods of assessing and measuring students' metacognitive thinking through online environments. Online metacognitive thinking assessments in specific domain assignments and settings can be used to measure students' metacognitive thinking skills (Veenman et al., 2014). Researchers used measurement tools in the form of otter tasks, multiplechoice questions, and open-ended questions. Zheng, Li, Zhang, and Sun (2019) conducted an assessment using online-based group metacognitive scaffolding (GMS) to measure students' metacognitive behavior in a small group in the class. The results show that GMS has a significant impact on learners' metacognitive behavior in a small group. Furthermore, Altiok et al. (2019) measuring metacognitive thinking using an integrated video portfolio online environment, and the results showed an increase in the level of metacognitive thinking of students in foreign language learning. Some of these studies only focus on measurement and assessment methods on learning in general education and have not touched on vocational education, which has its learning characteristics. Appropriate learning models are used in vocational education, namely work-based learning, project-based learning, or contextual teaching and learning. An authentic and performance- 
based learning assessment method is needed (Wimmers, 2016). Therefore, it is necessary to develop a measurement instrument and an authentic and performance Assessment rubric that aims to produce a metacognitive skill Blended Learning Management System (BLEMS) assessment instrument and rubric suitable for vocational education. Development and evaluation of assessment instruments and rubrics using a student-centered assessment approach in which students are the subject and object of assessment reflect their learning and peer and teacher assessment approaches (Koç et al., 2015).

This study aims to produce a metacognitive skill assessment rubric and produce a BLEMS metacognitive skill assessment model for vocational education that met validity, practicality, and effectiveness. This study aims to provide a rubric guide for assessing metacognitive skills and an alternative metacognitive skill assessment model through BLEMS according to the project and workbased learning characteristics in vocational education.

\section{Vocational Education}

Vocational education and training (Technical and Vocational Education and Training) includes theoretical and practical learning content developed in a school, training institution, or company environment. Based on this limitation, the knowledge and skills referred to here can be understood as technical knowledge and skills and knowledge of values and identities in a complex world of work. This vocational education paradigm is also not only a learning process in the school environment. Still, it can be done in non-formal training environments such as training institutions and agencies or companies (Sudira, 2017). Pavlova (2009) states that traditionally the primary purpose of vocational education is to prepare graduates to work directly. Vocational education must provide specialized reproductive training based on instructor instruction, emphasizing knowledge of a particular industrial sector and containing specific skills or trade tricks. Vocational Education and Training (VET) has played a central role in supporting the school-to-work transition for youth. VET for productive work is considered essential for economic and social development (Jung et al., 2019). An essential emphasis of vocational education is developing specific work-related skills or skills to prepare students to enter the world of work. Simultaneously, general education emphasizes equipping students with broad knowledge and basic mathematics and communication (Hampf \& Woessmann, 2017). Based on these theories, it can be concluded that general vocational education aims to prepare graduates to work in specific sectors. This educational function transforms work competencies, knowledge of the world of work, and collaboration and interaction between workers.

\section{Metacognitive Skill}

The study of metacognitive thinking has been associated with John Flavell as an expert in cognitive development since the 1970s. Flavell, Miller, and Miller (1979) suggested that metacognition refers to awareness, monitoring, and regulating a person's cognitive processes. In line with this, Yusuf et al. (2017) explained that metacognitive refers to the principle of organizing thinking through controlling one's cognitive processes. The metacognitive component consists of awareness and monitoring, and evaluation. These components can improve students' abilities in problem-solving.

Furthermore, Jacobs and Paris (1987) explained that metacognition refers to thinking about thinking. Metacognition focuses on self-regulated review: what people know and how they apply that knowledge to specific tasks. Next, Moshman (2018) explains more about metacognitive theory as a systematic framework used to describe and direct the process of cognition, cognitive knowledge, and cognitive regulation skills. A fundamental distinction is made between knowledge of metacognitive knowledge and metacognitive regulation. Knowledge of cognition refers to what individuals know about their cognition or cognition in general. It consists of declarative knowledge (learning about things), procedural knowledge (knowing how to do things), and conditional knowledge (knowing why and when). Cognition regulation refers to metacognitive activities that help control a person's thinking or learning. Three crucial, widely recognized skills are planning (strategy selection and resource allocation), monitoring (understanding awareness and task performance), and evaluation (assessing the product and process of organizing one's learning). 
Furthermore, Schraw and Moshman (1995) explains more about the classification of metacognitive knowledge and metacognitive regulation. In metacognitive knowledge, declarative knowledge includes knowledge about oneself as a learner and what factors influence a person's performance. Procedural knowledge refers to knowledge about the implementation of procedural skills. Conditional knowledge refers to knowing when and why to implement various cognitive actions. Whereas regulation or metacognitive regulation, which is categorized into three dominations, namely, planning the cognitive process (planning), monitoring the cognitive process (monitoring), and evaluating the process of cognition (evaluation). Planning involves selecting the right strategy and allocation of resources that affect performance. Examples include making predictions before reading, sequencing strategies, and allocating time or attention selectively before starting a task. Monitoring refers to a person's online awareness of task understanding and performance. The ability to engage in regular self-evaluation while studying is an example. Evaluation refers to the assessment of a person's product and learning management process. Common examples include re-evaluating one's goals and conclusions. Still, in line with some of the above definitions of metacognitive, Lai, Beimers, and Dolan (2011) explained that metacognition could be divided into two components: metacognitive knowledge and metacognitive regulation. Metacognitive regulation monitors one's cognition and includes planning activities, awareness of self-understanding and work performance, and evaluating the efficacy aspects of monitoring processes and strategies.

Based on the metacognitive description above, it is concluded that metacognitive thinking is the awareness of thinking about how we think, how we organize thinking strategies to complete certain tasks well. Metacognitive thinking can be categorized into two sub-categories: metacognitive knowledge and metacognitive regulation. Metacognitive knowledge is divided into declarative, procedural, and conditional thinking. Meanwhile, metacognitive regulation is divided into planning, monitoring, and evaluation processes.

In terms of learning in vocational education, these two categories allow to be measured and assessed. However, considering the performance-based and product-based assessment methods in vocational education, metacognitive regulation (planning, monitoring, and evaluation) is more likely to be measured. Klerk, Veldkamp, and Eggen (2018) explained that vocational education emphasizes performance-based assessments where students learn by doing. This was confirmed by Wimmers (2016) that at the end of the vocational education program or professional education program, every student must achieve standardized work competence so that in this education program, performancebased assessment is a general method for assessing practical competence in an authentic context. Learners can measure their metacognitive thinking skills through the process of planning, monitoring, and evaluating their performance and the projects or products they make.

\section{Blended Learning}

Blended learning is a combination of various modalities (on-site, independent, and webbased learning), media of delivery (internet, lectures, PowerPoint presentations, textbooks); teaching methods (face-to-face or technology-based/online sessions) and web-based technology (wikis, chat rooms, blogs, textbooks, online courses). A combination (hybrid) is carried out depending on learning objectives, course content, lecturer experience, teaching style, student characteristics, etc. (Kofar, 2016).

Furthermore, Kaur (2013) defines blended/hybrid learning from multiple perspectives: holistic perspective, educational perspective, pragmatic perspective, corporate training perspective, CLO-Chief learning officer perspective. Holistic perspective, the delivery of learning using a variety of media formats, including the integration of learning media into traditional classrooms (f2f) or into online learning environments regardless of the combination of synchronous or asynchronous media. Educational perspective is a lecture that integrates $\mathrm{f} 2 \mathrm{f}$ lecture activities with online pedagogical content. F2f lectures have been partially replaced by online activities, especially in synchronous and online-asynchronous classes. Pragmatic perspective is lectures taught both in the classroom and at a distance using different pedagogic combination strategies. Corporate training perspective is using various learning media formats to deliver a curriculum or course. CLO-Chief learning officer 
perspective is a learning strategy that integrates several communication modalities (both synchronous and asynchronous).

The success of blended learning depends not only on the quality of the course and the virtual environment but also on how lecturers and students are prepared to work in a virtual learning environment. It also depends on preparing materials and learning activities by lecturers and lecturers and students' technical abilities. In particular, to use all the tools/features offered by the Learning Management System (LMS), such as the metacognitive features of assignments and quizzes.

\section{RESEARCH METHOD}

This study uses Research and Development (R\&D) research. R\&D chosen according to the purpose of this study is to produce a metacognitive assessment model product. This study adopted Borg and Gall (1983) development procedure, which consisted of 10 stages, as can be seen in Figure 1: preliminary research, research planning, early product development, expert validation, early test, product revision, field test, product revision, implementation, and dissemination. The development of metacognitive instruments and rubrics based on the previously reviewed theories of Schraw and Moshman (1995) and Lai et al. (2011). Where metacognitive regulation includes three aspects, namely: the planning process, the monitoring process, and the evaluation process of the project being undertaken, each of the two experts validated the instruments, materials, and media.

The data used is a scale with a range of 1-4. The criteria for the validation results were further categorized into: very good $(>3.40)$, good $(2.90-3.40)$, sufficient $(2.30-2.80)$, poor $(1.60-2.20)$, and very less $(<1.60)$ (Widoyoko, 2011). Meanwhile, the instrument reliability test used the Intraclass Correlation Coefficient (ICC) technique using the SPSS version 19 application. The initial trial was conducted by involving ten students to test the metacognitive rubric that had been integrated into BLEMS. The second trial was conducted through the blended learning method to determine the practicality and effectiveness of the metacognitive instrument and rubric in measuring metacognitive thinking skills. The trial subjects were 35 students who took the Control and Data Acquisition Practical Courses in the Mechatronics Vocational Education Study Program, Faculty of Engineering, Universitas Negeri Makassar, Indonesia. The type of data used in this research is quantitative data. Quantitative data is obtained from the metacognitive thinking measurement score that combines self, peer, and teacher assessment and uses the BLEMS method and the project-based learning model.

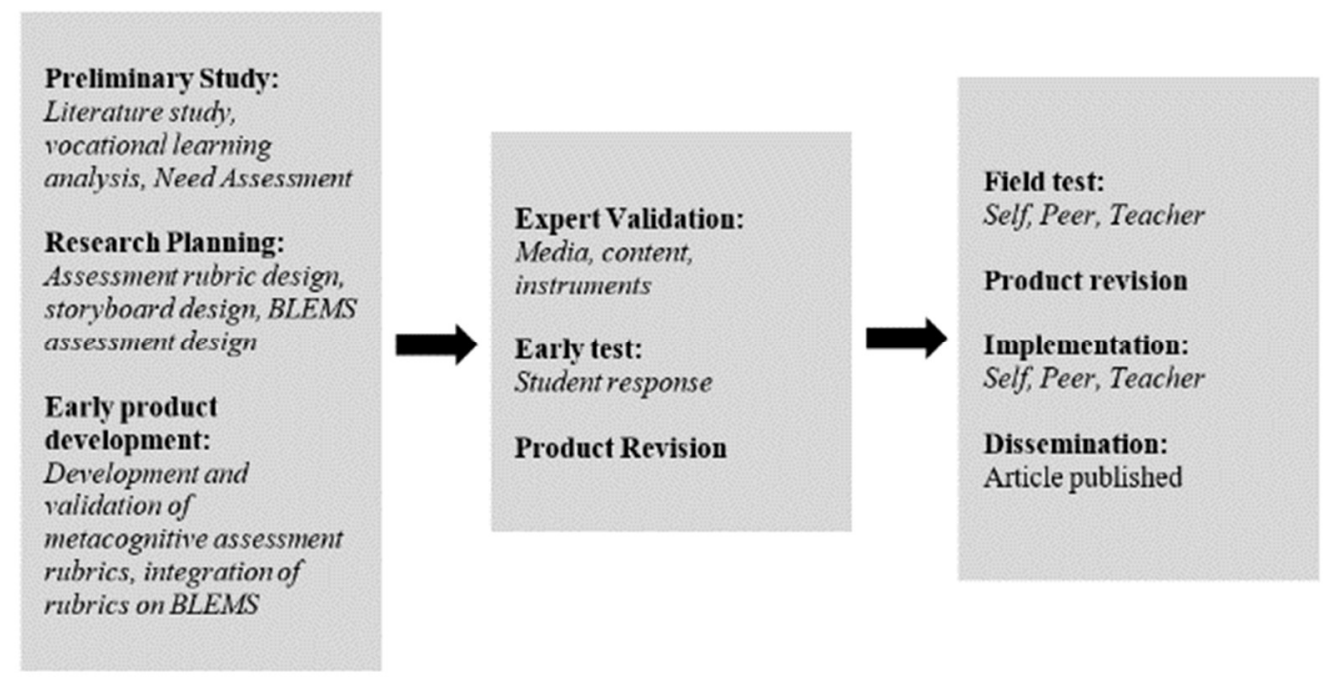

Figure 1. The Procedure for Developing a Metacognitive Assessment Model 


\section{RESULT AND DISCUSSION}

\section{Result}

\section{Planning}

Assessment models and rubrics are compiled at this planning stage based on the previously reviewed metacognitive thinking theory. This study uses the metacognitive regulation theory, divided into planning, monitoring, and evaluation processes. Table 1 is a complete rubric that has been compiled based on the theoretical indicators outlined earlier.

Table 1. Metacognitive Skill Assessment Rubric

\begin{tabular}{|c|c|c|c|c|c|}
\hline $\begin{array}{c}\text { Metacognitive } \\
\text { Aspect }\end{array}$ & Indicator & Score 1 & Score 2 & Score 3 & Score 4 \\
\hline $\begin{array}{l}\text { 3. Evaluation } \\
\text { (Evaluating the } \\
\text { results of his } \\
\text { work) }\end{array}$ & $\begin{array}{l}\text { - The report contains clear, } \\
\text { coherent, and complete } \\
\text { information. } \\
\text { - Reports are presented by } \\
\text { including the appropriate } \\
\text { images. } \\
\text { - The report states that all } \\
\text { project work processes } \\
\text { are carried out in } \\
\text { accordance with the } \\
\text { stages. } \\
\text { - The report writes a good } \\
\text { conclusion that } \\
\text { summarizes the final } \\
\text { goal of working on a } \\
\text { previously written } \\
\text { project. }\end{array}$ & $\begin{array}{l}\text { The report } \\
\text { contains clear, } \\
\text { coherent, and } \\
\text { complete } \\
\text { information. }\end{array}$ & $\begin{array}{l}\text { - The report } \\
\text { contains clear, } \\
\text { coherent, and } \\
\text { complete } \\
\text { information. } \\
\text { - Reports are } \\
\text { presented by } \\
\text { including the } \\
\text { appropriate } \\
\text { images. }\end{array}$ & $\begin{array}{l}\text { - The report contains } \\
\text { clear, coherent, and } \\
\text { complete } \\
\text { information. } \\
\text { - Reports are } \\
\text { presented by } \\
\text { including the } \\
\text { appropriate images. } \\
\text { - The report states } \\
\text { that all project work } \\
\text { processes are carried } \\
\text { out according to the } \\
\text { stages. }\end{array}$ & $\begin{array}{l}\text { - The report contains } \\
\text { clear, coherent, and } \\
\text { complete information. } \\
\text { - Reports are presented } \\
\text { by including the } \\
\text { appropriate images. } \\
\text { - The report states that } \\
\text { all project work } \\
\text { processes are carried } \\
\text { out in accordance with } \\
\text { the stages. } \\
\text { - The report writes a } \\
\text { good conclusion that } \\
\text { summarizes the final } \\
\text { goal of working on a } \\
\text { previously written } \\
\text { project. }\end{array}$ \\
\hline
\end{tabular}




\section{Validation}

Validation was conducted by two instrument experts, two material experts, and two media experts, in this case, an expert in the learning management system (LMS) field. The instrument's validated aspects relate to the construction, language, material, and metacognitive rubric aspects used as assessment guides. Meanwhile, media aspects are validated based on aspects of appearance and use. All instruments integrated online media throughout the project work process, making it easier for students to make planning documents, monitor project progress, and evaluate final project reports. Furthermore, an initial trial was conducted on ten students to see whether the metacognitive assessment rubric that had been integrated into BLEMS worked well in the system. Figure 2 presents data visualization of the results of material validation, media, and student responses.

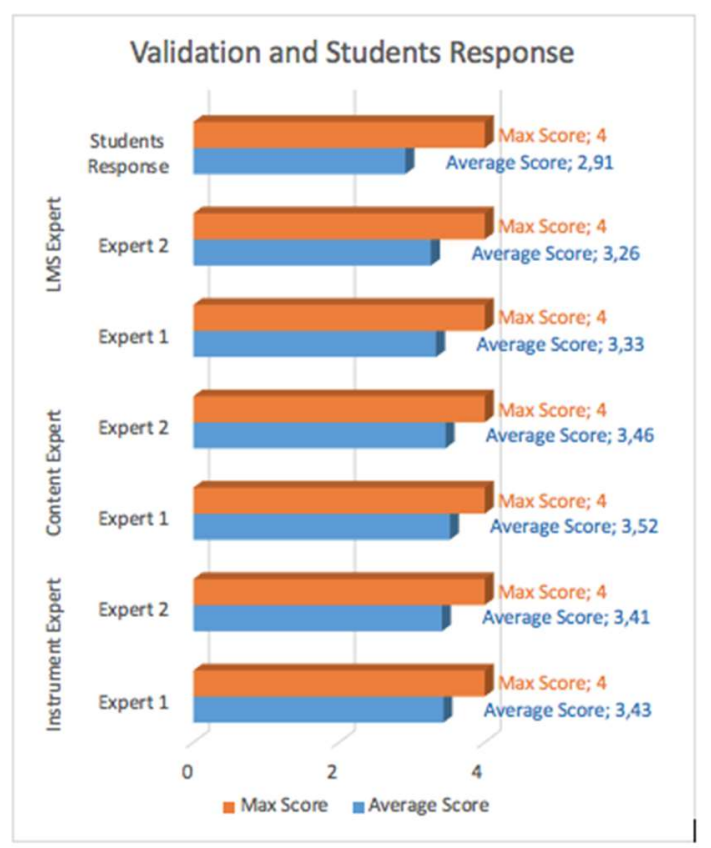

Figure 2. Results of Instrument Validation and LMS, as well as Preliminary Trial Results

Figure 2 shows that the instrument expert, content expert, and LMS expert, each consisting of two experts, agree to give a score in the good category (the average score is above 3) when referring to the validation result criteria. The student response aspect also shows a score in the good category (2.91). This means that the quality aspects of the instruments and metacognitive rubrics, and the media/LMS, are in a good category and are suitable for use in collecting research data in the form of students' metacognitive thinking scores.

Table 2. Kendall's tau and Spearman's rho Correlation Value

\begin{tabular}{|c|c|c|c|c|}
\hline & & & reater1 & reater2 \\
\hline \multirow[t]{6}{*}{ Kendall's tau_b } & reater1 & Correlation Coefficient & 1.000 & $.887^{* *}$ \\
\hline & & Sig. (2-tailed) & & .000 \\
\hline & & $\mathrm{N}$ & 182 & 182 \\
\hline & reater2 & Correlation Coefficient & $.887 * *$ & 1.000 \\
\hline & & Sig. (2-tailed) & .000 & \\
\hline & & $\mathrm{N}$ & 182 & $182^{\circ}$ \\
\hline \multirow[t]{6}{*}{ Spearman's rho } & reater1 & Correlation Coefficient & 1.000 & $.971^{* *}$ \\
\hline & & Sig. (2-tailed) & & .000 \\
\hline & & $\mathrm{N}$ & 182 & 182 \\
\hline & reater2 & Correlation Coefficient & $.971 * *$ & 1.000 \\
\hline & & Sig. (2-tailed) & .000 & \\
\hline & & $\mathrm{N}$ & 182 & $182^{\circ}$ \\
\hline
\end{tabular}

\footnotetext{
**. Correlation is significant at the 0.01 level (2-tailed).
} 
In the instrument reliability test using the Intraclass Correlation Coefficient (ICC) technique. Table 2 presents the results of the ICC analysis or the results of the Inter-Rater score correlation analysis using the SPSS for Windows application with two data from instrument experts. Table 2 shows that Kendall's correlation value is 0.887 . Then the Spearman's rho correlation value was 0.971 . These two correlation values indicate that the inter-rater agreement's value is quite impressive for the instrument developed in this study. Based on these analysis results, the instrument designed can be reliable based on the Intraclass Correlation Coefficient (ICC) analysis.

\section{Development}

This stage of development, rubric development, and rubric integration in BLEMS were carried out. Figure 3 is a view of the metacognitive rubric on the planning aspects that have been integrated into BLEMS. Figure 3 shows a metacognitive rubric consisting of 4 rating scales; each scale contains several assessment criteria from the aspect of project planning, one of the metacognitive aspects. Students and faculty directly choose one of the points corresponding to the assessed student project and work planning report's contents.

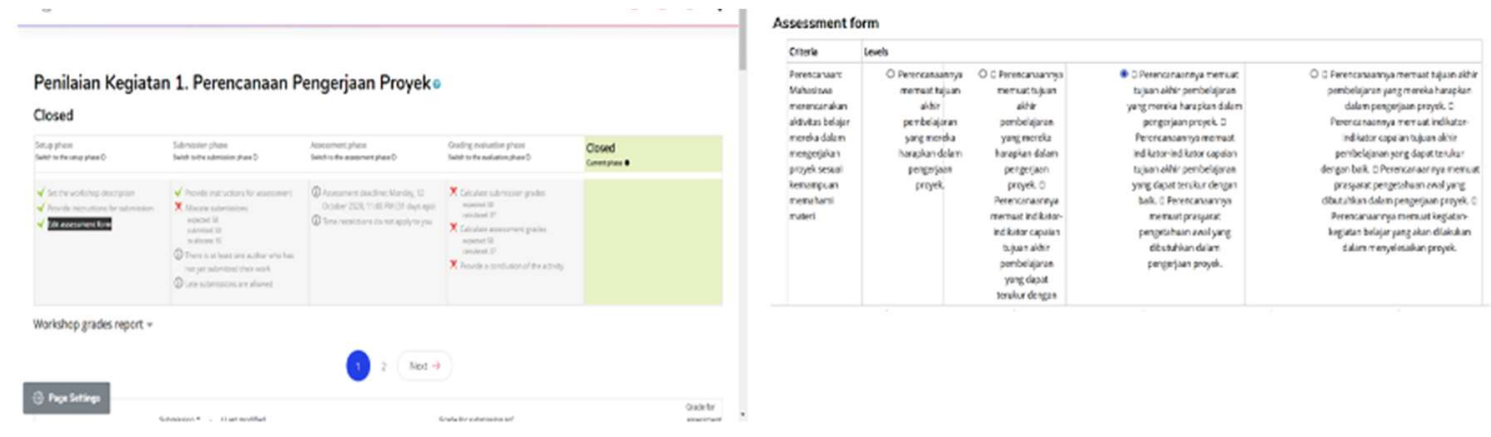

Figure 3. Metacognitive Rubric Integrated into BLEMS

\section{Testing}

The next stage is conducting field trials on the learning process with a project-based learning model. This learning process applies the BLEMS method, which combines two learning cycles: online and face-to-face. Online-based learning cycles are used to strengthen basic materials or theories before students carry out direct project work in the data acquisition and control engineering laboratory. Also, online methods are used to integrate metacognitive assessment rubrics and instruments. Figure 4 shows the Peer, Self, and Teacher Assessment results of students at BLEMS.

Figure 4 shows the results of peer assessment (Grades received), self-assessment (grades are given), and teacher assessment (Grade for Submission and Grade for Assessment). Each student provides a score to the other three students and receives a score from the three students based on the assessment rubric. After that, the Teacher also gives a score based on the same assessment rubric. These scores are then downloaded in excel file format for further processing by weighting each score. The score from the self-assessment is given a weight of 20, the score from the peer assessment is given a weight of 30 , and the score from the teacher assessment is given a weight of 50 so that the maximum score is 100 .

Figure 5 presents the final score from the measurement results of students' metacognitive thinking as a whole in project work. Figure 5 shows the scores of the three aspects of metacognitive thinking, namely project planning, monitoring, and evaluation. The score comes from three sources, namely peer, self, and teacher assessment. The peer assessment score (24.19) was categorized as high in the planning aspect because it was close to the maximum score (30). Likewise, self scores (18.38) and teacher assessment (36.29) were also categorized as high because they were close to the maximum scores, namely 20 and 50 . Scores on the metacognitive aspects of monitoring and evaluation also showed high peer, self, and teacher assessment scores. 


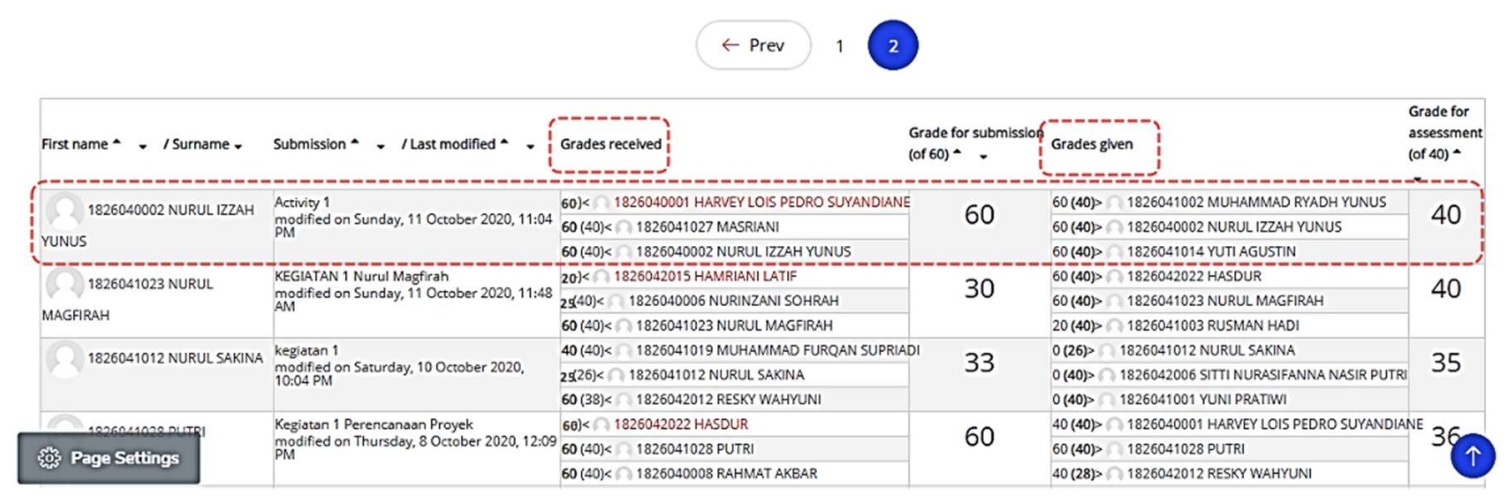

Figure 4. Peer, Self, and Teacher Assessment on BLEMS

The scores on the graph can also be seen that the peer assessment scores from the planning, monitoring and evaluation aspects are not much different. Likewise, the self-scores and teacher assessment do not differ much from the three metacognitive aspects. This means that the metacognitive thinking rubric is effectively used as a guide for assessment by students and lecturers in vocational education. These scores have shown the level of students' metacognitive thinking according to the characteristics of the vocational education assessment method based on performance-based assessment and project-based learning models.

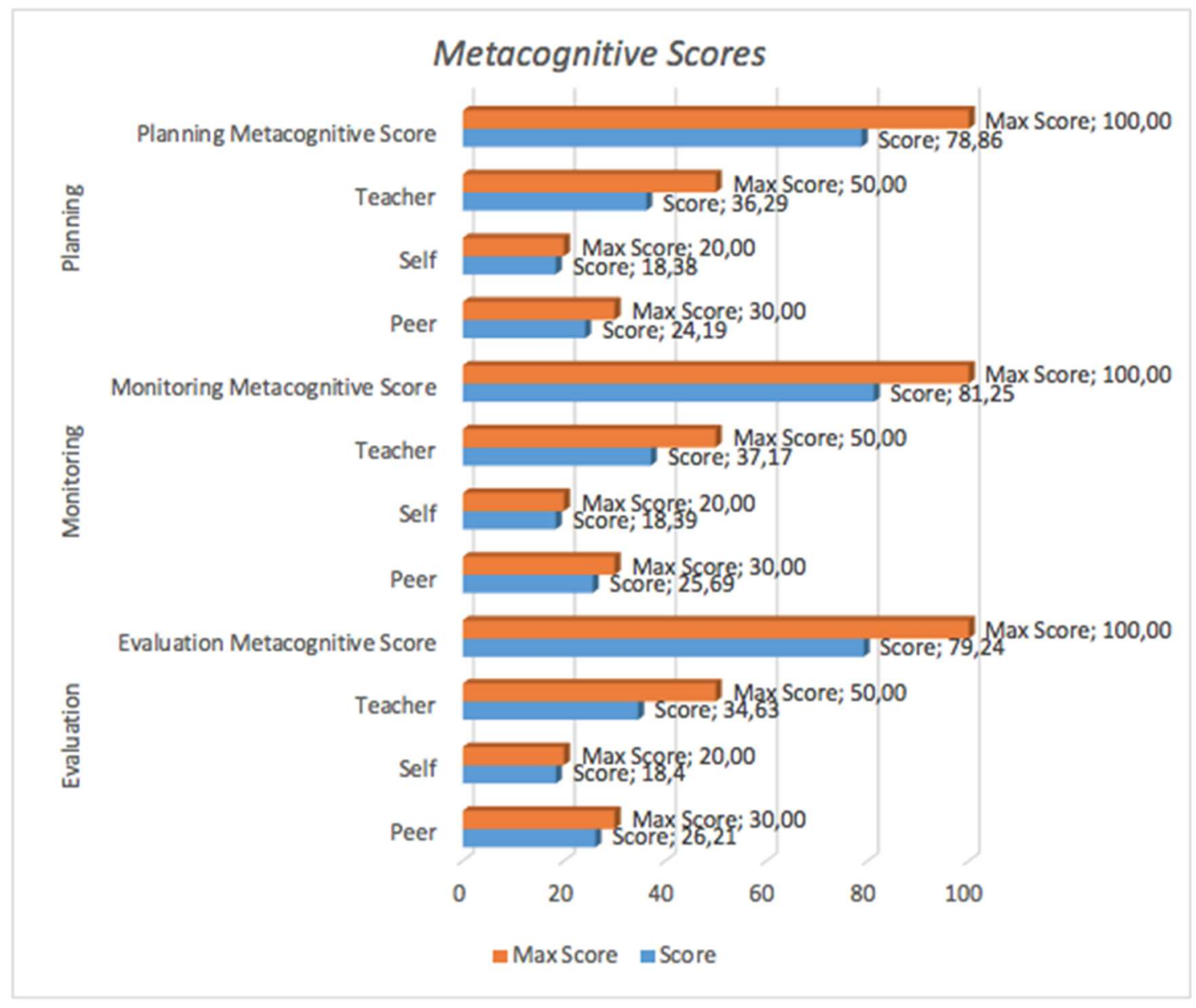

Figure 5. Measurement Results of Students' Metacognitive Thinking 


\section{Discussion}

The result shows that the assessment model, instruments, and rubrics that have been integrated with the BLEMS method have succeeded in measuring students' metacognitive thinking skills. This is because this assessment model allows students to assess their answers (self-assessment) and provides an opportunity for students to assess their peers' responses (peer-assessment). Students are involved in assessing and evaluating answers based on the scoring rubric given to BLEMS. This encourages students to be more proactive in assessing their metacognitive thinking skills to support the development of their metacognitive skills. This is in line with Vaughan's research results, which apply the Triad Approach Assessment (self, peer, teacher assessment) to blended learning. This assessment approach can support the development of students' metacognitive skills (Koç et al., 2015). This study's results are also by the theory previously described, namely metacognitive or metacognitive thinking, the awareness of thinking about how we think, and how we organize thinking strategies to complete certain tasks well. Metacognitive thinking can be categorized into two subcategories, namely metacognitive knowledge and metacognitive regulation. Metacognitive knowledge is divided into declarative, procedural, and conditional consideration considerations. Meanwhile, metacognitive regulation is divided into planning, monitoring, and evaluation processes.

In the context of learning in vocational education, these two categories allow to be measured and assessed. However, considering the performance-based and product-based assessment methods in vocational education, metacognitive regulation (planning, monitoring, and evaluation) is more likely to be measured. Klerk et al. (2018) explained that vocational education emphasizes performance-based assessments where students learn by doing. This was confirmed by Wimmers (2016) that at the end of the vocational education program or professional education program, every student must achieve standardized work competence so that in this education program, performancebased assessment is a general method for assessing practical competence in an authentic context. Also, Project-Based Learning (PBL) is an alternative learning model in vocational education where students can plan, design, and reflect on their learning through projects (Doppelt, 2005). PBL is a student-centered learning model where students work on a project, make project work reports, and communicate the report to peers and teaching staff (Marx et al., 1997). Therefore, students can measure their metacognitive thinking skills through the process of planning, monitoring, and evaluating their performance and the projects or products they make.

The BLEMS method (online and face to face) in project-based learning can optimize the learning process. The online form is used to strengthen basic theory before students work on projects directly (face to face) in the laboratory to optimize the three metacognitive aspects, namely planning, monitoring, and evaluating project work. Figure 6 is a metacognitive assessment model that combines self, peer, and teacher assessment in BLEMS using a project-based learning model.

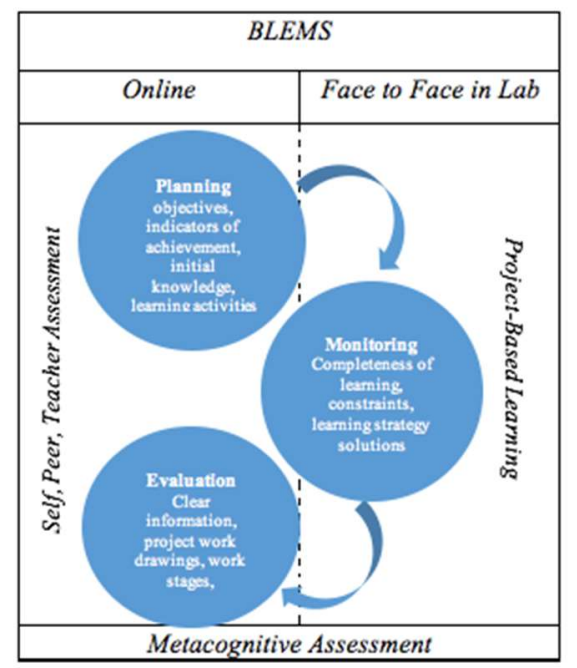

Figure 6. Metacognitive Assessment Model in Vocational Education 
Figure 6 shows an assessment model that combines self, peer, and integrated teacher assessment in BLEMS with a project-based learning model. BLEMS consists of online learning and face-to-face in the laboratory. The online method assesses the three metacognitive aspects, namely planning, monitoring, and evaluation, based on the metacognitive rubric integrated into the online environment. While the face-to-face method is carried out in the laboratory for project work for students. Face-to-face also enables educators to carry out authentic assessments of the three metacognitive aspects (planning, monitoring, evaluation). This assessment model's implementation's final result is the metacognitive thinking score of students in vocational education.

In general, the learning evaluation method in BLEMS, which is only teacher-centered, of course, does not involve students in assessing and reflecting on their evaluation results. Their answers from carrying out activities at LMS were evaluated only by one party by the educators. Students only see the score or final score of each test they pass, so they can't see which aspects they lack. However, through this assessment model (self-assessment and peer-assessment), students are actively involved in assessing their higher-order thinking skills, namely metacognitive thinking.

\section{CONCLUSIONS}

This study produced an assessment rubric to determine students' metacognitive thinking skills in project-based learning in Vocational Education. The development assessment rubric into three activities: planning, monitoring, and evaluation, then integrated into the BLEMS method. This study also produced a metacognitive assessment model in BLEMS for vocational education. After testing experts' validity, testing practicality through student responses, and testing effectiveness through self, peer, and teacher assessment, this resulting model is tested. The resulting model integrates three self-assessment activities, peer-assessment, and teacher assessment for the ProjectBased Learning (PBL) learning model. This assessment model can measure students' metacognitive thinking skills, especially in project-based learning and work-based learning in vocational education.

Further research can be combining quantitative data and qualitative data to obtain a more indepth teacher assessment regarding the effectiveness of assessing students' metacognitive thinking in vocational education. Further research can do using other learning models based on vocational Education or general Education by adopting the model produced in this study.

\section{REFERENCES}

Al-araibi, A. A. M., \& Naz, M. (2018). Technological aspect factors of e-learning readiness in higher education institutions : Delphi technique. Education and Information Technologies, 24, 567590. https://doi.org/10.1007/s10639-018-9780-9

Altıok, S., Başer, Z., \& Yükseltürk, E. (2019). Enhancing metacognitive awareness of undergraduates through using an e-educational video environment. Computers and Education, 139, 129-145. https://doi.org/10.1016/j.compedu.2019.05.010

Borg, W. R., \& Gall, M. D. (1983). Educational research : An introduction (4th ed.). Longman.

Costello, E., Holland, J., \& Kirwan, C. (2018). The future of online testing and assessment : question quality in MOOCs. International Journal of Educational Technology in Higher Education, 15(42), 1-14.

Doppelt, Y. (2005). Assessment of project-based learning in a MECHATRONICS context. Journal of Technology Education, 16(2), 7-24. https://doi.org/10.21061/jte.v16i2.a.1

Earl, L. M., Katz, M. S., Manitoba Education, Citizenship, and Y., \& Western and Northern Canadian Protocol for Collaboration in Education. (2006). Rethinking classroom assessment with purpose in mind. In Learning. Winnipeg: Manitoba Education, Citizenship \& Youth. https://doi.org/10.4135/9781446214695

Flavell, J. H., Miller, P. H., \& Miller, S. A. (1979). Cognitive development (L. Pearson (ed.); 4th ed.). Prentice Hall. 
Gotoh, Y. (2016). Development of critical thinking with metacognitive regulation. International Conference on Cognition and Exploratory Learning in Digital Age, Celda, 353-356.

Hampf, F., \& Woessmann, L. (2017). Vocational vs. general education and employment over the life-cycle: New evidence from PIAAC. CESifo Economic Studies, 63(3), 255-269. https://doi.org/10.1093/cesifo/ifx012

Hsu, C. M., Yeh, Y. C., \& Yen, J. (2009). Development of design criteria and evaluation scale for web-based learning platforms. International Journal of Industrial Ergonomics, 39(1), 90-95. https://doi.org/10.1016/j.ergon.2008.08.006

International Labour Organisation (ILO). (2019). A skilled workforce for strong, sustainable and balanced growth: a G20 training strategy (1st ed., Issue November). International Labour Organization.

Jacobs, J. E., \& Paris, S. G. (1987). Children's metacognition about reading: issues in definition, measurement, and instruction. Educational Psychologist, 22(3-4), 255-278. https://doi.org/10.1080/00461520.1987.9653052

Johnson, R. (2004). Peer assessments in physical education. Journal of Physical Education, Recreation \& Dance, 75(8), 33-40. https://doi.org/10.1080/07303084.2004.10607287

Jung, S., Chul, J., \& Nam, S. (2019). Impact of vocational education and training on adult skills and employment: An applied multilevel analysis. International Journal of Educational Development, 66(April 2019), 129-138. https://doi.org/10.1016/j.ijedudev.2018.09.007

Kaur, M. (2013). Blended learning - Its challenges and future. Procedia - Social and Behavioral Sciences, 93, 612-617. https://doi.org/10.1016/j.sbspro.2013.09.248

Kew, S. N., \& Petsangsri, S. (2018). Examining the motivation level of students in e-learning in higher education institution in Thailand: A case study. Education and Information Technologies, 23, 2947-2967. https://doi.org/10.1007/s10639-018-9753-z

Klerk, S. De, Veldkamp, B. P., \& Eggen, T. J. H. M. (2018). A framework for designing and developing multimedia- based performance assessment in vocational education. Educational Technology Research and Development, 66(1), 147-171. https://doi.org/10.1007/s11423-0179559-5

Koç, S., Liu, X., \& Wachira, P. (2015). Assessment in online and blended learning environments. Information Age Publishing.

Kofar, G. (2016). A study of EFL instructors' perceptions of blended learning. Procedia - Social and Behavioral Sciences, 232, 736-744. https://doi.org/https://doi.org/10.1016/j.sbspro.2016.10.100

Lai, E. R., Beimers, J. N., \& Dolan, B. (2011). Metacognition: A literature review research report. In Pearson's Research Reports (Issue April). http://images.pearsonassessments.com/images/tmrs/Metacognition_Literature_Review_Final. pdf

Mahande, R. D., Susanto, A., \& Surjono, H. D. (2017). The dynamics of mobile learning utilization in vocational education: Frame model perspective review. The Turkish Online Journal of Educational Technology, 16(4), 65-76. https://files.eric.ed.gov/fulltext/EJ1160603.pdf

Mane, F., \& Corbella, T. (2017). Developing and running an establishment skills survey: Guide to anticipating and matching skills and jobs volume 5 (Vol. 5). Publications Office of the European Union. https://doi.org/10.2816/413514

Marx, R. W., Blumenfeld, P. C., Krajcik, J. S., \& Soloway, E. (1997). Enacting project-based science. The Elementary School Journal, 97(4), 342-358. https://www.journals.uchicago.edu/doi/abs/10.1086/461870 
Mhouti, A. El, \& Nasseh, A. (2017). Enhancing collaborative learning in Web 2 . 0-based e-learning systems : A design framework for building collaborative e-learning contents. Education and Information Technologies, 22, 2351-2364. https://doi.org/10.1007/s10639-016-9545-2

Moshman, D. (2018). Metacognitive theories revisited. Educational Psychology Review, 30(2), 599606. https://doi.org/10.1007/s10648-017-9413-7

Otero, J. P. G. de. (2019). UNESCO-UNEVOC trends mapping: Innovation in TVET. UNESCOUNEVOC. https://unevoc.unesco.org/pub/tm_innovation.pdf

Pavlova, M. (2009). The vocationalization of secondary education: The relationships between vocational and technology education. In International Handbook of Education for the Changing World of Work (pp. 1805-1821). Springer. https://doi.org/10.1007/978-1-4020-5281-1_122

Schraw, G., \& Moshman, D. (1995). Metacognitive theories. Educational Psychology Review, 7(4), 351-371. https://doi.org/10.1007/BF02212307

Sudira, P. (2017). TVET abad XXI: Filosofi, teori, konsep, dan strategi pembelajaran vokasional (Hartono (ed.); 2nd ed.). UNY Press.

Veenman, M. V. J., Bavelaar, L., Wolf, L. De, \& Haaren, M. G. P. Van. (2014). The on-line assessment of metacognitive skills in a computerized learning environment. Learning and Individual Differences, 29, 123-130. https://doi.org/10.1016/j.lindif.2013.01.003

Widoyoko, S. E. P. (2011). The evaluation of the learning programme a practical guide for educators and prospective educators. Pustaka Pelajar.

Wimmers, P. F. (2016). Innovation and change in professional education 13 assessing competence in professional performance across disciplines and professions (M. Mentkowski (ed.); 1st ed.). Springer. https://doi.org/10.1007/978-3-319-30064-1

Xiong, Y., \& Suen, H. K. (2018). Possibilities, challenges and future directions. International Review of Education, 64, 241-263. https://doi.org/10.1007/s11159-018-9710-5

Yusuf, Y., Rodding, R., Awang, H., \& Mukhtar, I. (2017). Metacognitive strategies in promoting the development of generic competences in high TVE in Malaysia. Pertanika Journal of Social Science and Humanities, 25, 247-256.

Zheng, L., Li, X., Zhang, X., \& Sun, W. (2019). The effects of group metacognitive scaffolding on group metacognitive behaviors, group performance, and cognitive load in computer-supported collaborative learning. The Internet and Higher Education, 42(19), 13-24. https://doi.org/10.1016/j.iheduc.2019.03.002

Zwart, D. P., Luit, J. E. H. Van, Noroozi, O., Goei, S. L., Zwart, D. P., Luit, J. E. H. Van, Noroozi, O., Goei, S. L., Zwart, D. P., Luit, J. E. H. Van, Noroozi, O., \& Goei, S. L. (2017). The effects of digital learning material on students' mathematics learning in vocational education The effects of digital learning material on students ' mathematics learning in vocational education. Cogent Education, 29(1). https://doi.org/10.1080/2331186X.2017.1313581 